\title{
Makna simbolik bahasa ritual pertanian masyarakat Bali
}

\author{
Ni Wayan Sartini \\ Universitas Airlangga \\ Email: yaniwiratha@yahoo.com
}

\begin{abstract}
The purpose of this study is to conserve the agricultural culture and to review the symbolic meaning and local wisdom in certain agricultural rituals. This research is conducted in Subak Kedua Pasedahan Yeh Lauh, Peguyangan Kangin Village, West Denpasar, Bali. Data is collected using the methods of interview and literature review. From the data collected, there are twenty four ritual steps found that should be performed by the farmers in Bali. Those indicate farmers' religious nature and appreciation of their cultural tradition. Each ritual from sowing to harvesting contains symbolic meanings and cultural values embraced as the guidance in farming life. From the analyses concerning its ritual and tools used, it is concluded that the symbolic meaning of ritual discourse performed by the farmers are: (1) expressing gratitude to God for all abundant harvest grace; (2) asking permission for farming to the motherland as the manifestation of God in term of the ruler of the land; (3) asking for safety for having a successful agriculture to God (Goddess Sri); (4) offerings to the rice field rulers to be kept away from pests that damage plants; (5) keeping the environmental balance -in the philosophy of Hindu society in Bali, it is one of Tri Hita Karana's best practices.
\end{abstract}

Keywords: agricultural ritual, Bali society, farmer, symbolic meaning, local wisdom

\begin{abstract}
Abstrak
Penelitian ini dilakukan untuk melestarikan ritual pertanian dan mengkaji makna simbolik dan kearifan lokal yang terdapat dalam wacana ritual pertanian. Lokasi penelitian dilakukan di Subak Kedua Pasedahan Yeh Lauh Desa Peguyangan Kangin Kecamatan Denpasar Barat, Bali. Pengumpulan data dilakukan dengan metode wawancara dan pustaka. Dari data yang telah dikumpulkan, ditemukan ada dua puluh empat tahapan ritual yang seharusnya
\end{abstract}


dilakukan oleh petani. Berbagai ritual yang dilakukan oleh petani di Bali menunjukkan sifat religius petani dan sangat menghargai tradisi budayanya. Setiap ritual yang dilakukan mulai dari awal pengerjaan sawah sampai panen mengandung makna simbolik dan nilai-nilai budaya yang dianut dan dipedomani sebagai penuntun dalam kehidupan bertani. Dari analisis terhadap wacana ritual pertanian, dapat disimpulkan bahwa makna simbolik ritual yang dilakukan petani adalah (1) ucapan terima kasih kepada Tuhan atas anugrah panen yang baik dan melimpah, (2) permohonan ijin kepada Ibu Pertiwi sebagai manisfestasi Tuhan penguasa tanah karena para petani akan mengerjakan sawah; (3) permohonan keselamatan kepada Tuhan (Dewi Sri) agar pertanian dapat berhasil baik, (4) persembahan kepada penguasa sawah agar terhindar dari segala macam hama yang merusak tanaman, (5) menjaga keseimbangan lingkungan. Dalam filosofi masyarakat Hindu Bali hal itu merupakan penerapan konsep Tri Hita Karana.

Kata kunci: ritual pertanian, masyarakat Bali, petani, makna simbolik, kearifan lokal

\section{Pendahuluan}

Dan alam beberapa tahun terakhir Bali menghadapi masalah yang sangat serius yaitu maraknya alih fungsi lahan dari lahan pertanian (persawahan) menjadi lahan permukiman, perhotelan, resor, dan sebagainya. Seperti yang dikatakan oleh Sutawan (2008:18) bahwa pembangunan sarana dan prasarana perkantoran dan pariwisata yang terjadi terus menerus mempunyai konsekuensi logis adanya alih fungsi lahan sehingga mempersempit lahan pertanian. Situasi ini sangat ironis, karena UNESCO pada sidang ke-36 tanggal 29 Juni 2012 di St. Petersburg, Rusia telah menetapkan Subak sebagai warisan budaya dunia yang merupakan sistem pengelolaan air pertanian Bali dengan sebutan Cultural Landscape of Bali Province: The Subak System as a Manifestation of the Tri Hita Karana Philosophy. Hal ini berarti, seandainya pertanian di Bali lenyap, berarti subak pun akan hilang sebagai warisan budaya dunia.

Makin masif dan akseleratifnya alih fungsi lahan sawah di Bali dapat mengancam keberlangsungan tradisi ritual pertanian. Ritual pertanian sebagai salah satu tradisi petani di Bali merupakan 
aktivitas yang juga diatur oleh subak. Tradisi ritual tersebut diwariskan dari para leluhur untuk tujuan-tujuan tertentu dan mengandung kearifan lokal. Kearifan lokal tersebut mengandung nilai-nilai budaya dan filosofi yang tinggi bagi masyarakat Bali serta memberi pedoman dalam berperilaku terhadap lingkungan sehingga terwujud keseimbangan alam dan lingkungannya. Pertanian di Bali sangat unik karena dikelola oleh lembaga irigasi tradisional yang disebut subak (Sriartha \& Wayan Windia, 2015:327). Selanjutnya dikatakan, subak sebagai kelembagaan lokal terkait langsung dengan pengelolaan lahan sawah dan air irigasi. Dengan berlandaskan pada filosofi Tri Hita Karana (THK) subak telah diakui perannya sangat efisien dan efektif dalam mengelola kelestarian sumberdaya pertanian, terutama air irigasi. Keunikan subak dapat dilihat dari organisasinya yang bersifat otonom dan fleksibel, sistem pembagian air yang adil, pemeliharaan jaringan irigasi dilakukan secara gotong royong serta adanya tata upacara ritual atau awig-awig pertanian yang juga diatur oleh subak.

Agar tradisi-tradisi budaya yang mengandung nilai-nilai luhur kearifan lokal tersebut tidak lenyap, diperlukan usaha-usaha dan strategi dalam melestarikannya. Penelitian ini akan membahas makna simbolik ritual pertanian yang dilakukan oleh masyarakat petani Bali dengan tujuan untuk melestarikan salah satu tradisi budaya masyarakat Bali yang hampir punah karena ritual-ritual tersebut semakin jarang dilakukan. Makna simbolik dalam hal ini mengacu pada makna simbol-simbol yang merupakan bagian terkecil dari ritual yang menyimpan makna dari tingkah laku atau kegiatan dalam upacara ritual yang bersifat khas pertanian masyarakat Bali. Simbol-simbol terkecil itu meliputi sarana sesajen dan mantra (wacana ritual) yang dalam masyarakat Bali juga disebut saa. Makna simbolik piranti (sarana) ritual dan wacana ritualnya (saa) tersebut berkaitan erat dengan filosofi kehidupan dan kearifan budaya masyarakat petani Bali. Oleh sebab itu, makna simbolik ritual tidak dapat dilepaskan dari keberadaan wacana ritual (saa) sebagai data bahasa yang kemudian dihubungkan dengan konteks sosial budaya serta filosofi masyarakat Bali. Sehubungan dengan itu, penelitian ini merupakan penelitian etnolinguistik yaitu kajian kebahasaan atau kebudayaan dalam etnis Bali yang yang mengkaji 
bahasa dalam kegiatan agama atau ritual khususnya ritual pertanian pada masyarakat Bali. Model kajian seperti itu juga disebut sebagai kajian linguistik kebudayaan (linguistik antropologi).

Penelitian ini dilakukan di Subak Kedua Pasedahan Yeh Lauh Desa Peguyangan Kangin Kecamatan Denpasar Barat. Subak ini memiliki tata aturan dalam pengelolaan subak yang tertuang dalam pustaka Awig-awig Subak Kedua Pasedahan yeh Lauh Desa Peguyangan Kangin Kecamatan Denpasar Barat yang disahkan tanaggal 17 September 1981. Dalam aturan tersebut tertulis batas-batas wilayah subak, tata aturan bermasyrakat, tata aturan dan etika (sukrata tata pasubakan), tata aturan pelaksanaan ritual pertanian, tata aturan dalam pelaksanaan awig-awig dan sebagainya. Berkaitan dengan awig-awig ritual, para petani selalu mematuhi arahan dari pengurus subak atau diistilahkan dengan surat subak pekaseh baik untuk ritual persawahan maupun ritual nangluk mrana (penolak hama) dan kerta masa (jeda tanam) (hasil wawancara dengan informan Mei 2017). Aktivitas pertanian di Subak ini masih cukup aktif dalam berbagai kegiatan. Masalah pertemuan (indik paruman) dibagi dua yiatu rapat dengan warga (krama) subak dan pengurus subak. Rapat tersebut diadakan sewaktu-waktu untuk tujuan-tujuan tertetu. Dalam waktu-waktu tertentu Pekaseh yang memimpin subak ini mengadakan pertemuan dengan para petani.

Artikel ini menggunakan data kualitatif yaitu data berbentuk uraian kata-kata, kalimat dan narasi, dan ungkapan yang berkaitan dengan makna simbolik ritual pertanian pada masyarakat Bali. Teknik penentuan informan dilakukan secara purposif yaitu berdasarkan tujuan yang ingin dicapai peneliti(Endrawara, 2006:115). Selanjutnya untuk menjaring data diawali dengan penentuan informan kunci yang memiliki kemampuan reflektif, meluangkan waktu untuk wawancara, bersemangat, dan memiliki pengetahuan yang luas mengenai permasalahan yang diteliti. Data penelitian ini dikumpulkan lewat observasi, wawancara dan studi pustaka. Kemudian analisis data dilakukan secara deskriptif kualitatif dan interpretatif. Data yang diperoleh dikritisi dan diklasifikasikan berdasarkan asumsi kultural serta dengan sikap fleksibel, reflekstif, dan objektif (Endraswara, 2006:15). Hasil analisis akan disajikan dengan metode informal yaitu penyajian 
hasil analisis dengan kata-kata dan ragam ilmiah.

\section{Kajian pustaka}

Penelitian tentang hal-hal yang berkaitan dengan pertanian telah banyak dilakukan. Penelitian-penelitian itu antara lain Bandana (2005) meneliti tentang “Wacana Ritual Penanaman Padi di Kecamatan Selamadeg Barat Kabupaten Tabanan : Kajian Linguistik Kebudayaan". Penelitian Bandana tersebut mengkaji makna kontekstual wacana ritual tanpa membahas makna-makna simbolik dan strategi budaya dalam melestarikan ritua-ritual tersebut. Tidak dijelaskan juga bagaimana menjaga tradisi pertanian tersebut agar tidak tergerus oleh globalisasi dan modernisasi. Penelitian lanjutan tentang wacana ritual pertanian oleh Bandana dkk. (2010) membahas bentuk, fungsi, dan makna wacana ritual pertanian dalam "Wacana Ritual sebagai Usaha Pelestarian Bahasa Bali". Penelitian ini sangat linguistis sifatnya karena banyak membahas struktur pola-pola kalimat dari teks wacana tersebut. Tidak dikaji lebih jauh fungsi sosial dan keberadaan wacana ritual tersebut dikaitkan dengan pelestarian budaya dan tradisi.

Netra (2012) meneliti "Wacana Ritual Melong Pare Balu Komunitas Petani Adat Bayan, Lombok Barat: Kajian Etnografi". Penelitian ini membahas wacana-wacana ritual yang digunakan petani adat Bayan dalam bercocok tanam menggunakan metode etnografi dengan observasi partisipasi tidak terlibat untuk mengumpulkan data. Dari analisis yang telah dilakukan ditemukan bahwa wacana ritual Melong Pare Bulu memiki tema dan skematik sebagai struktur mikro, sehingga dengan demikian dapat diketahui bahwa wacana ritual dilakukan secara bertahap. Penggunaan unsur-unsur linguistik dalam wacana ritual tersebut menunjukkan cara bertutur masyarakat tersebut. Dari kajian yang telah dilakukan, penelitian tersebut tidak menganalisis secara komprehensif nilai dan kearifan ekologis yang terdapat di dalam wacana ritual petani adat Bayan. Di samping itu juga tidak dibahas strategi budaya untuk melestarikan tradisi tersebut sebagai kearifan lokal untuk menunjang industri pariwisata. Kekurangan inilah yang memberi inspirasi kepada penulis untuk melakukan penelitian ini.

Berkaitan dengan pemaknaan terhadap suatu wacana budaya, 
Malinowski (dalam Hymes (1964) mengemukakan bahwa melalui etnolinguistik dapat ditelusuri bagaimana bentuk-bentuk linguistik (teks-teks) dipengaruhi oleh aspek budaya, sosial, mental, dan psikologis; apa hakekat sebenarnya dari bentuk dan makna serta bagaimana hubungan keduanya. Sejalan dengan itu gagasan Franz Boas sangat berpengaruh dalam pengembangan linguistik antropologi terutama pengaruhnya pada Sapir dan Whorf sehingga melahirkan konsep relativitas bahasa. Menurut tokoh ini bahasa (dalam hal ini wacana ritual) tidak dapat dipisahkan dari fakta sosial budaya masyarakat pendukungnya. Salah satu kontribusi Sapir (dalam Bonvillain,1997:49) yang sangat terkenal adalah gagasannya yang menyatakan bahwa analisis terhadap bahasa (kosa kata) suatu bahasa sangat penting untuk menguak lingkungan fisik dan sosial di mana penutur suatu bahasa bermukim. Dalam hal ini terjadi hubungan antara bahasa (kosakata) dan nilai budaya bersifat multidimensional.

Nilai-nilai budaya dan kearifan ekologis ritual pertanian ini dapat diketahui dari teks-teks ritual yang menyertai setiap pelaksanaan ritual. Teks-teks ritual ini memiliki nilai-nilai yang dapat dijadikan pedoman dalam menjaga kelestarian lingkungan. Bentuk-bentuk teks ritual tersebut mengandung nilai-nilai budaya yang tinggi. Nilai adalah sesuatu yang menyangkut baik dan buruk. Pepper (dalam Djajasudarma, 1997) menyatakan bahwa nilai mengacu pada minat, kewajiban, agama, kebutuhan, keamanan dan sebagainya. Secara definitif, Theodorson (1979) mengemukakan bahwa nilai merupakan sesuatu yang abstrak yang dijadikan pedoman serta prinsip-prinsip umum dalam bertindak dan bertingkah laku. Keterikatan orang atau kelompok terhadap nilai relatif sangat kuat dan bahkan bersifat emosional. Oleh sebab itu nilai -nilai dalam teks-teks ritual pertanian dapat dilihat sebagai pedoman bertindak dan sekaligus sebagai tujuan kehidupan itu sendiri.

Menurut Koentjaraningrat (1987:85) nilai budaya terdiri atas konsepsi-konsepsi yang hidup dalam alam pikiran sebagian besar warga masyarakat mengenai hal-hal yang mereka anggap mulia. Clyde Kluckhohn (1952) mendefinisikan nilai budaya sebagai konsepsi umum yang terorganisasi yang mempengaruhi perilaku 
yang berhubungan dengan alam, kedudukan manusia dalam alam, hubungan orang dengan orang dan tentang hal-hal yang diingini dan tak diingini yang mungkin bertalian dengan hubungan antara orang dengan lingkungan dan sesame manusia. Lebih lanjut Kluckhohn mengatakan bahwa nilai budaya merupakan sebuah konsep beruang lingkup luas yang hidup dalam alam pikiran sebagian besar warga suatu masyarakat mengenai apa yang berharga dalam dalam hidup. Sistem nilai itu menjadi pedoman yang melekat erat secara emosional pada diri seseorang atau sekumpulan orang, malah merupakan tujuan hidup yang diperjuangkan. Nilai-nilai tersebut merupakan wujud ideal dari lingkungan sosialnya. Dapat dikatakan bahwa sistem nilai budaya suatu masyarakat merupakan wujud konsepsional dari kebudayaan mereka yang seolah-olah berada di luar dan di atas para individu warga masyarakat.

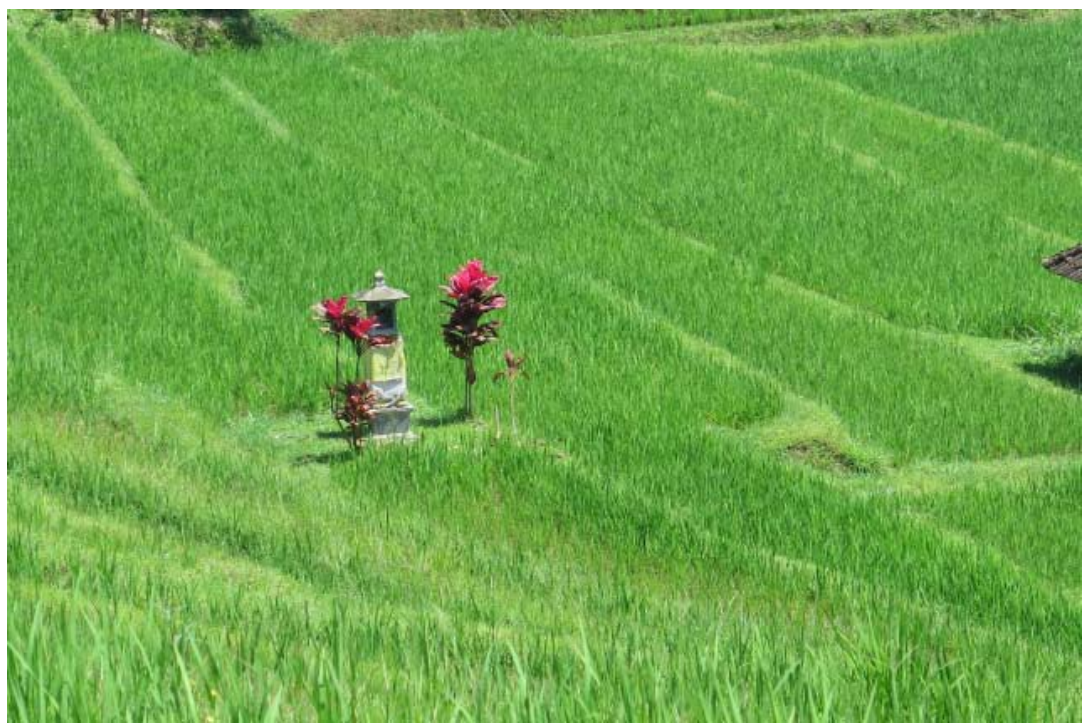

Foto 1. Hamparan sawah di Bali dengan tempat pemujaan pelinggih di tengahnya, tempat ritual subak dilaksanakan. (Foto Darma Putra)

\section{Makna simbolik}

Manusia dalam kehidupannya selalu berkaitan dengan simbolsimbol. Manusia adalah animal symbol, artinya bahwa pemikiran dan tingkah laku simbolis merupakan ciri yang betul-betul khas manusia dan bahwa seluruh kemajuan kebudayaan manusia 
mendasarkan diri pada kondisi-kondisi itu. Turner (1967 menyatakan bahwa "The symbol is the smallest unit of ritual which still retains specific properties of ritual behavior. It is the ultimate unit of specific structure in a ritual context". Simbol adalah unit atau bagian terkecil dalam ritual yang mengandung makna dari tingkah laku ritual yang bersifat khusus. Simbol tersebut merupakan unit pokok dari struktur khusus dalam konteks ritual (Endraswara, 2012:172). Sehubungan dengan itu Turner (1967) menyatakan "the ritual is an agregation of symbols" dan dikuatkan oleh Radcliffe-Brown (1979) bahwa tindakan ritual itu banyak mengungkapkan simbol, berarti analisis ritual juga harus diarahkan pada simbol-simbol ritual tersebut. Pada bagian lain (Spradley, 1997) menyatakan simbol sebagai unit terkecil menyimpan makna yang berkaitan dengan penuturnya dan menunjuk pada sesuatu. Jadi simbol adalah suatu tanda yang memberitahukan sesuatu kepada seseorang yang telah mendapatkan persetujuan umum dalam tingkah laku ritual.

Setiap simbol memiliki ciri khas. Turner (1967) membedakan ciri khas simnol menjadi; (a) multivokal, artinya simbol memiliki banyak arti, menunjuk pada banyak hal, pribadi, atau fenomen. Hal ini menunjukkan betapa kaya makna simbol ritual, (b) polarisasi symbol, karena simbol memiliki banyak arti sering ada arti simbol yang bertentangan, (c) unifikasi, artinya memiliki arti terpisah. Dengan menganalisis simbol ritual akan membantu menjelaskan secara benar nilai yang ada dalam masyarakat dan akan menghilangkan keragu-raguan tentang kebenaran sebuah penjelasan.

Dalam menganalisis makna simbol dalam aktivitas ritual, digunakan teori penafsiran Turner (1967) yakni (1) exegetical meaning yaitu makna yang diperoleh dari informan warga setempat tentang perilaku ritual yang diamati, (2) operational meaning yaitu makna yang diperoleh tidak terbatas pada informan saja melainkan dari tindakan yang dilakukan dalam ritual, (3) positional meaning yaitu makna yang diperoleh melalui interpretasi terhadap simbol dalam hubungannya dengan simbol lain secara totalitas.Tingkatan makna ini langsung dihubungkan pada pemilik simbol ritual. Makna suatu simbol ritual harus ditafsirkan ke dalam konteks simbol yang lain dan pemiliknya. 


\section{Makna simbolik ritual pertanian di Bali}

Dari data yang dikumpulkan ditemukan beberapa tahapan ritual yang dilakukan dalam pertanian. Dalam setiap tahapan upacara atau ritual pertanian dilengkapi dengan sarana dan mantra sebagai pelengkap ritual. Ritual dan sarana yang melengkapi ritual pertanian tersebut mengandung makna simbolik yang tidak lepas dari konsep dan falsafah hidup masyarakat Bali. Nilai yang terkandung dalam ritual pertanian tersebut menjadi pedoman yang melekat erat secara emosional pada diri masyarakat Bali terutama petani, bahkan merupakan tujuan hidup yang diperjuangkan. Rangkaian ritual yang dilakukan bukan semata-mata proses tanpa makna, tetapi setiap upakara atau ritual tersebut sarat makna simbolik dan makna budaya. Ritual tersebut mengandung kearifan lokal yang dapat memberikan tuntunan hidup untuk berperilaku serta berinteraksi dengan sesama mahkluk dalam sebuahkomunitas yang kompleks sehingga keteraturan dan keseimbangan hidup dapat terlaksana dengan baik. Keberadaan ritua-ritual tersebut merupakan implementasi dari Tri Hita Karana yang terdiri atas tiga hubungan harmonis yaitu pawongan, palemahan, dan parahyangan.

Berdasarkan wawancara yang dilakukan terhadap informan dan kajian pustaka "Aci -aci Subak Kedua Pasedahan Yeh Lauh", ditemukan wujud-wujud ritual yang dilakukan oleh petani mulai dari tahapan awal sampai akhir pengerjaan sawah (panen). Wujud ritual pertanian yang dimaksud adalah wujud persembahan berupa sesajen dan diiringi dengan mantra atau wacana ritual sebagai pelengkap ritual. Berikut adalah wujud ritual pertanian dan makna simbolik ritual tersebut.

\section{(a) Ritual Mendak / Mapag Toya}

Kata mendak artinya 'menjemput', kata toya 'air'. Ada juga yang menyebut ritual ini dengan istilah mapag toya yang maknanya juga 'menjemput air'. Kata mapag dan mendak berbeda dalam tingkatan bahasa namun memiliki arti yang sama yaitu 'menjemput'. Upacara ini merupakan bagian dari ritual pertanian sebagai simbol menjemput air di sumber air sebagai sumber kehidupan agar tanaman padi dapat tumbuh subur tanpa kekeringan.

Kata mendak atau mapag dalam konteks ini tidak bermakna 
leksikal (denotasi) namun memiliki makna kontotasi sebagai ungkapan rasa syukur kepada penguasa air (Tuhan) dan mohon ijin agar diberkahi air yang melimpah untuk kesuburan tanaman pertanian. Upacara itu dilakukan di Pura Panghulun Subak (Subak Hulu). Dalam masyarakat petani di Bali, ritual ini dilakukan sebagai bentuk terima kasih dan penghormatan (astiti bhakti) kepada Bhatari Danu (dalam hal ini dewa yang bersemayam di Danau Batur) sebagai manifestasi Tuhan Yang Mahakuasa (Ida Sang Hyang Widi Wasa) yang telah memberikan kesuburan (kawibuhan). Dalam mantra yang diucapkan yang mengiringi ritual, disebutkan Bhatara Gangga sebagai dewi atau bhetari yang bersemayam di Sungai Gangga. Dalam agama Hindu Sungai Gagngga adalah sungai suci sebagai sumber air yang dapat mengalirkan air kesegala penjuru termasuk sawah-sawah.

\section{(b) Ritual Ngendag Memacul}

Kata ngendag berasal dari akar kata endag' terbit' (Kersten,1980). Ngendag adalah kata kerja yang bermakna 'memulai'. Memacul artinya 'mencangkul'. Di beberapa tempat ritaul ini disebut ngendagin. Dengan demikian ritual ngendag memacul adalah upacara untuk memulai mencangkul sawah dengan mencangkul tiga kali pengalapan 'hulu sawah' secara simbolis diiringi dengan mantra (wacana ritual) yang diucapkan oleh petani dan ditujukan kepada Dewi Sri yaitu "Om Bhatari Sri wastu ya nama swaha".

Wacana ritual ini bermakna permohonan dan pemujaan kepada Dewi Sri untuk meminta ijin memulai mencangkul. Saat memulai mencangkul (ngawit numbeg) petani akan mengucapkan mantra "Om Ibu Pertiwingulun anedahasa, wredyastu ya namah swaha". Tujuannya pemujaan kepada Ibu Pertiwi (tanah) dan permohonan agar diberikan keselamatan ketika memulai mencangkul sawah.

Upakara atau ritual ngendag memacul dengan mantra dan sarananya adalah simbol bahwa masyarakat petani Bali menghormati ciptaan Tuhan sehingga dalam kegiatan tersebut diawali dengan mantra meminta ijin kepada Dewi Sri sebagai dewi padi. Dalam mitos-mitos budaya, sampai saat ini Dewi Sri diyakini sebagai asal mula tanaman padi (Suaka, 2013). Dalam mantra memulai mencangkul pun (ngawit numbeg) mantra yang diucapkan 
tersebut sebagi simbol pemujaan dan permohonan ijin kepada Ibu Pertiwi (tanah) agar diberikan keselamatan dalam pekerjaan. Ideologi yang tampak dari ritual dan mantra ngendag memacul adalah penerapan Tri Hita karana yakni hubungan manusia dengan Tuhan Yang Mahakuasa (parahyangan).

Wacana ritual yang diucapkan ketika Ngendag Memacul wujudnya berbeda-beda. Artinya ada wujud teks yang panjang dan ada wujud teks yang pendek seperti pada mantra di atas. Bandingkan dengan yang terdapat pada penelitian Bandana, dkk. (2010) memulai bekerja di sawah (Ngendagin) mantra yang diucapkan oleh petani yang disebut saa lebih panjang seperti berikut.

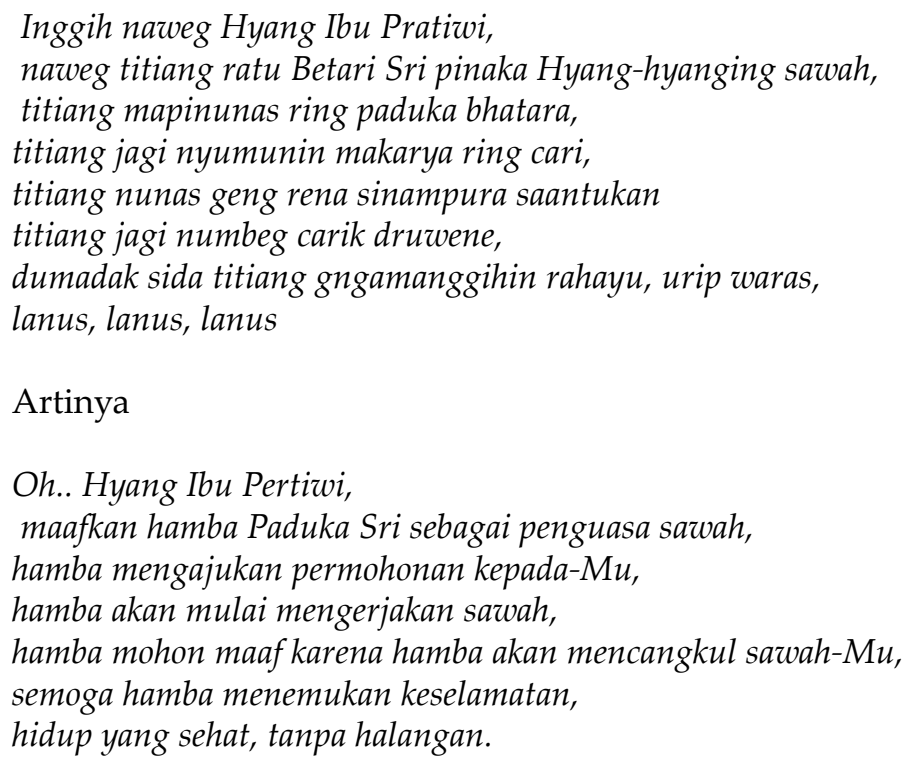

Pada dasarnya, inti saa (wacana ritual) yang pendek dan panjang sama yaitu permohonan ijin kepada Dewi Sri dan kepada Ibu Pertiwi. Teks-teks ritual tersebut menunjukkan konsep yang dianut oleh masyarakat petani di Bali yaitu konsep Tri Hita Karana yaitu adanya tiga macam hubungan yaitu hubungan manusia dengan Tuhan, manusia dengan manusia, dan hubungan manusia dengan alam lingkungannya. Teks ritual di atas merepresentasikan bahwa para petani sebagai makluk ciptaannya meminta ijin untuk melakukan suatu pekerjaan pada tanah ciptaan Tuhan yang 
manifestasinya dalam bentuk Ibu Pertiwi. Para petani sadar betapa sawah yang akan dikerjakannnya adalah ciptaan Tuhan sehingga memohon agar pekerjaan tersebut dapat dilakukan tanpa halangan dan hambatan.

\section{(c) Upacara Ngurit}

Ngurit atau disebut juga mawinih adalah upacara untuk penyemaian benih. Dalam proses ngurit ini petani melaksanakan ritual dengan sarana banten atau sesajen yang terdiri atas nasi kojongan, bunga pucuk bang, segehan putih kuning, yang diletakkan di hulu sawah (pengalapan). Sesaji atau banten tersebut merupakan bagian terkecil dari ritual yang menyimpan sesuatu makna dari tingkah laku atau kegiatan dalam ritual yang bersifat khas dan mengandung makna simbolik bagi petani. Sesajen tersebut dihaturkan kepada Hyang Ibu Pertiwi yang disertai dengan saa sebagai berikut.

\footnotetext{
Ratu betara Surya, Ratu betara Hyang Pertiwi, tiang nyebar bibit, mangda ten kaon,

labda karya bibit

Ong Hyang Ibu Pertiwi, ngulun aminta nugraha, taneman ingulun hempunen sida mahurip waras, Ong Sri, Sri, yanamah swaha
}

Makna simbolik yang terdapat dapat ritual Ngurit ini adalah permohonan anugrah dan perlindungan kepada Dewa Surya (Matahari) dan Ibu Pertiwi (tanah) karena petani akan mulai menanam benih. Mohon perlindungan agar benih-benih yang akan ditanam dapat tumbuh dengan baik di atas tanah sebagai ciptaan Tuhan Yang Mahakuasa. Makna simboliknya adalah bahwa masyarakat petani Bali adalah masyarakat yang religius yang percaya kepada Tuhan Yang Mahakuasa sehingga apa pun yang dilakukan selalu ingat dan mohon anugrah-Nya. Hal ini termasuk dalam salah satu konsep Tri Hita Karana yaitu tiga hubungan manusia dengan Tuhan, sesama, dan lingkungan.

\section{(d) Upacara Nandur}

Ritual Nandur adalah ritual yang dilakukan untuk mulai menanam padi. Sebelum memulai menanam padi sawah diupacarai 
dengan sesajen-sesajen tertentu. Dalam pustaka pedoman Aci-aci Subak Kedua"sarana sesajen yang dihaturkan pada ritual ini adalah bubuh putih, canang, cau petik, cau mumbul, penyeneng, pebersihan, banten danan serta kayu penyugjug (dapdap, andong, kayu puring, kayu sisih, kayu temen). Sesaji tersebut mengandung simbol-simbol yang berkaitan dengan tradisi dan kepercayaan masyarakat petani Bali. Wacana ritual (saa) yang diucapkan pun merupakan permohonan anugrah kepada Tuhan agar dewa-dewa manifestasi Ida Sang Hyang Widi Wasa (Tuhan) menghidupkan dan menyuburkan tanaman padi yang akan mulai ditanam. Saa yang diucapkan oleh petani sebelum melakukan aktivitas nandur sebagai berikut.

Ratu betara, Sang Hyang Ibu pertiwi,

Titiang jagi nandur mangkin

Ledang pakulun Ida anguripana sarwa tumuwuh

Mangda sinamian tanamen tiang anutugaken tahun

Mangda rahayu, selamet, ten kaon, labda karya

Artinya

Ya Tuhan sebagai Sang Hyang Ibu Pertiwi

Saya akan menanam padi

Semoga berkenan menghidupkan semua tumbuh-tumbuhan

Semoga semua tanaman hamba tumbuh subur

semuanya menjadi panjang umur, sepanjang tahun

Semoga selamat, selamat, tidak rusak, dan lancar pekerjaan hamba

(e) Ritual pantun mayusa 12 dina, 17 dina, 27 dina, 35 dina, 42 dina, 70 dina.

Pantun mayusaberasal darikata pantun'tanaman padi' mayusa artinya 'berumur, berusia'. Rangkaian ritual pertanian yang dilakukan ini sesuai dengan umur tanaman padi yaitu 12 hari, 17 hari, 27 hari, 35 hari, 24 hari dan 70 hari. Setiap peringatan terhadap usia tanaman padi tersebut dilakukan ritual sesuai dengan usia tanaman padi. Hal ini menunjukkan sebuah tradisi budaya memperlakukan tanaman padi ibaratnya manusia seperti dalam tradisi Hindu di Bali yang selalu melakukan ritual ketika seorang anak memasuki usia-usia tertentu. Di daerah lain di Bali ketika tanaman padi berusia 12 hari disebut juga upakara mubuhin 'menghaturkan bubur'. Upacara ini dilakukan dengan sesajen tertentu yang diletakkan di petak sawah 
di segala penjuru mata angin. Dalam tuntunan upakara disebutkan sebagai berikut.

Disampune pantune matuwuh 12 dina, sakadi rarene sampun mayusa 12 dina, irika kalaksanayang upacara negteg atma pramananing pantun.

Irika ngaturang bubuh ring carike.

Banten sane katur nasi bubuh mawadah suyuk, madaging canang atanding.

Genah maturan ring pengalapan ring sor."

Teks di atas menyimbolkan bahwa tanaman padi ibaratnya seorang anak (sekadi rarene 'seperti seorang anak kecil) yang berusia 12 hari, dilakukan ritual meneguhkan roh (jiwa) tanaman agar selanjutnya menjadi subur. Ibarat anak kecil, tanaman dihaturkan bubuh (bubur) karena masih bayi disertai dengan sarana lain seperti canang sari yang diletakkan di hulu sawah (pengalapan). Sarana ritual dari usia 12 hari selanjutnya juga berbeda sesuai dengan usia tanaman padi.

Kearifan budaya dan nilai simbolik yang dapat dilihat dari tahapan ritual usia tanaman padi adalah perlakuan yang humanis dengan merawat dengan baik tanaman padi seperti merawat manusia dari bayi sampai dewasa. Hal itu terlihat dari sesajen awal mempersembahkan bubuh 'bubur' kemudian canang bersarana (meraka) nyahnyah gringsing, tipat dampulan, blayang dan sebagainya. Dari segi bentuknya makin tua usia tanaman padi sarana upakaranya makin kompleks wujudnya.

Pada usia tanaman padi 35 hari disebut dedinan kapertama (peringatan usia 1 bulan). Sama halnya dengan ritual manusia, pada usia satu bulan Bali yaitu 35 hari juga dilakukan ritual dedinan pertama. Ketika tanaman padi berusia 35 hari sarana ritualnya semakin kompleks antara lain nanceb sanggah catu, sesajen ketipat dampulan, asem panca pala, kalungah maksturi, bjayang muah ketipat sari, mesawen kayu sugih, kayu gegirang. Memberi persembahan kepada Rare Angon yaitu nasi takilan, ulam bawang, sambel telengis, tipat lepet, maulam sudang taluh dan tak berem. Ritual juga disertai juga dengan pecut lidi 3 batang, berisi uang kepeng bolong, bertalikan benang anyar. Sarana dan proses ritual ini sesuai dengan usia tanaman padi yang sudah mulai remaja sehingga perlu dilakukan 
ritual agar tanaman padi tidak rusak dan dapat menghasilkan panen yang berlimpah. Secara umum makna simbolik tersebut adalah karena setiap tahapan ritual pasti memiliki tujuan yang baik yaitu persembahan kepada Tuhan dan mohon anugrah agar tanaman padi dapat berhasil panen yang baik dan melimpah.

\section{(f) Ritual Byakukung}

Kata byakukung berasal dari kata bya dan kukung. Bya dari kata byut 'bahaya', kata kukung berasal dari bahasa Jawa Kuno makukung 'badan', tertelungkup bungkuk, bagian tengah terangkat ke atas (Mardiwarsito, 1978:194 dalam Bandana, 2010). Badan yang tertelungkup bungkuk itu menyerupai orang yang sedang hamil. Pendapat lain mengatakan bahwa byakukung berasal dari bya 'prabea' dan kung 'kasmaran'. Dalam hal ini disebut patemoning sukla lawan swanita, kama bang lawan kama putih.

Ritual byakukung ini adalah ritual untuk tanaman padi yang mulai ngidam (beling). Atau upacara (ritual) saat tanaman mulai mengandung. Ritual byakukung ini adalah ritual untuk menghilangkan bahaya (untuk keselamatan) padi yang sedang hamil dan siap untuk melahirkan (Bandana, dkk. 2010). Upacara byakukung juga disebut ngiseh. Secara umum tujuan ritual ini adalah agar tanaman padi berbuah lebat (samah, nged) jauh dari segala macam gangguan dan bahaya.

Makna simbolik ritual tersebut mengandaikan tanaman padi adalah seorang perempuan yang mulai ngidam. Dalam ritual tersebut petani membuat sarana sesajen yaitu tempat sesajen berupa anyaman daun kelapa dan berbentuk bulat menyerupai perut wanita hamil. Dalam penelitian Bandana, dkk. (2010) disebutkan wujud ritualnya dilengkapi dengan sarana rujak, umbi-umbian, kelapa muda, dan obat-obatan. Rujak adalah makanan yang disukai perempuan ngidam. Beraneka jenis umbi-umbian antara lain talas, ketela pohon, biaung, ketela rambat semuanya dikukus yang dihaturkan mengandung makna sebagi makanan kaya karbohidrat yang diperlukan janin dalam tubuh si ibu yang sedang hamil. Kelapa muda yang berwarna kuning sebagai minumannya juga diyakini sebagai pembersih janin yang akan lahir. Dalam ritual itu juga dipersembahkan alat-alat untuk melahirkan seperti pisau dari 
bambu (ngaad), kulit telur, kunyit, dan benang diletakkan dalam sebuah tempat disebut kronjo. Pisau disimbolkan sebagai alat untuk memotong ari-ari-ari, telur simbol sebagai tempat ari-ari, kunyit obat luka, dan benang sebagai simbol pengikat tali pusar. Berdasarkan hal tersebut, makna simbolik secara umum upacara byakukung ini adalah bahwa padi yang akan mengeluarkan buah dianggap dan diperlakukan sama dengan wanita sedang mengidam atau hamil sehingga perlu diberikan makanan yang sesuai untuk kebutuhan orang hamil agar tetap sehat. Dalam konteks ini, padi yang mulai hamil dapat terus subur sampai panen tiba dengan hasil yang melimpah. Kearifan lokal yang ditemui adalah pada upacara atau ritual mabyakukung. Peralatan upacara seperti buah-buahan yang berasa asam, ubi dan air kelapa adalah bahan-bahan yang baik untuk perempuan hamil. Ritual byakukung mengibaratkan padi sebagai seorang perempuan mengidam, hamil dan akan melahirkan sehingga peralatan yang melengkapi ritual tersebut adalah pisau dari bambu, benang, kulit telur, kunir dan sebagainya sebagai sarana persiapan melahirkan.

Sangat menarik untuk menganalisis makna simbolik yang terkandung dalam ritual byakukung ini. Ritual ini kaya akan sarana yang mengandung simbol-simbol tertentu. Sesuai dengan Spradley (1997) simbol adalah suatu tanda yang membritahukan sesuatu kepada seseorang yang telah mendapatkan persetujuan umum dalam tingkah laku ritual. Turner (1967) menjelaskan bahwa melalui analisis simbol ritual akan membantu menjelaskan secara benar nilai yang ada dalam masyarakat dan akan menghilangkan keragu-raguan tentang kebenaran sebuah penjelasan. Dalam ritual byakukung ini disertai dengan wacana ritual sebagai pelengkap ritual yang intinya adalah mempersembahkan sesajen kepada Dewadewa sebagai manifestasi Tuhan agar dapat diterima dan mohon anugrahnya agar tanaman padi jauh dari segala ancaman dan bahaya sehingga menghasilkan panen yang baik dan berlimpah.

Menurut Suaka (2013) pengetahuan tradisional yang dikaitkan dengan pengetahuan modern ternyata tidakbertentangan. Padiyang baru mulai keluar dari buntingnya, bakal buahnya (putik) mencuat ke atas menyerupai kadal (kumalasan) tengah menjalani proses yaitu penyerbukan. Serbuk sari (bagaikan sperma) satu serbuk 
yang sangat halus yang bertengger di ujung-ujung merangnya padi akan berguguran. Serbuk sari yang jatuh ini ditadah dan diterima oleh bakal buah (bagaikan rahim ibu) yang terletak di bawahnya. Pertemuan inilah yang menyebabkan bakal buah itu dapat menjadi benar-benar berisi (bertunas). Tanpa kejatuhan serbuksari bakal buah tidak akan terjadi. Dalam teks ritual itu dikatakan ini adalah upacara Byukukung adalah upacara pada saat padi ngidam. Kata byukung berasal dari kata bya 'prabeya', kung' kasmaran, ngidam', patemoning sukla lawan swanita atau kama bang lawan kama putih. Secara umum maknanya adalah pertemuan antara serbuk sari dan kepala putik sehingga terjadi pembuahan.

Setiap upacara yang dilakukan dalam ritual pertanian tersebut dilengkapi dengan peralatan yang beraneka ragam. Petanda (fungsi) upacara-upacara tersebut ternyata dapat diterima secara logika ilmu pengetahuan. Penandaan atau makna simbolik yang dapat dipetik dari tradisi tersebut adalah ketika padi dalam keadaan beling (bunting) dan di sawah dipasang baling-baling, kober, sunari, dan kentongan (Suaka, 2013). Dengan peralatan itu akan menimbulkan sirkulasi anginyang tenang (ngesirsir) sehinggamembantu penyerbukan padi denganjatuhnya serbuk sari ke kepala putik.

Foto 2. Seorang wanita Bali mengaturkan sesajen di sawah sebagai bentuk pemujaan dan syukur atas padi ayng subur (Foto I Nyoman Martawan).

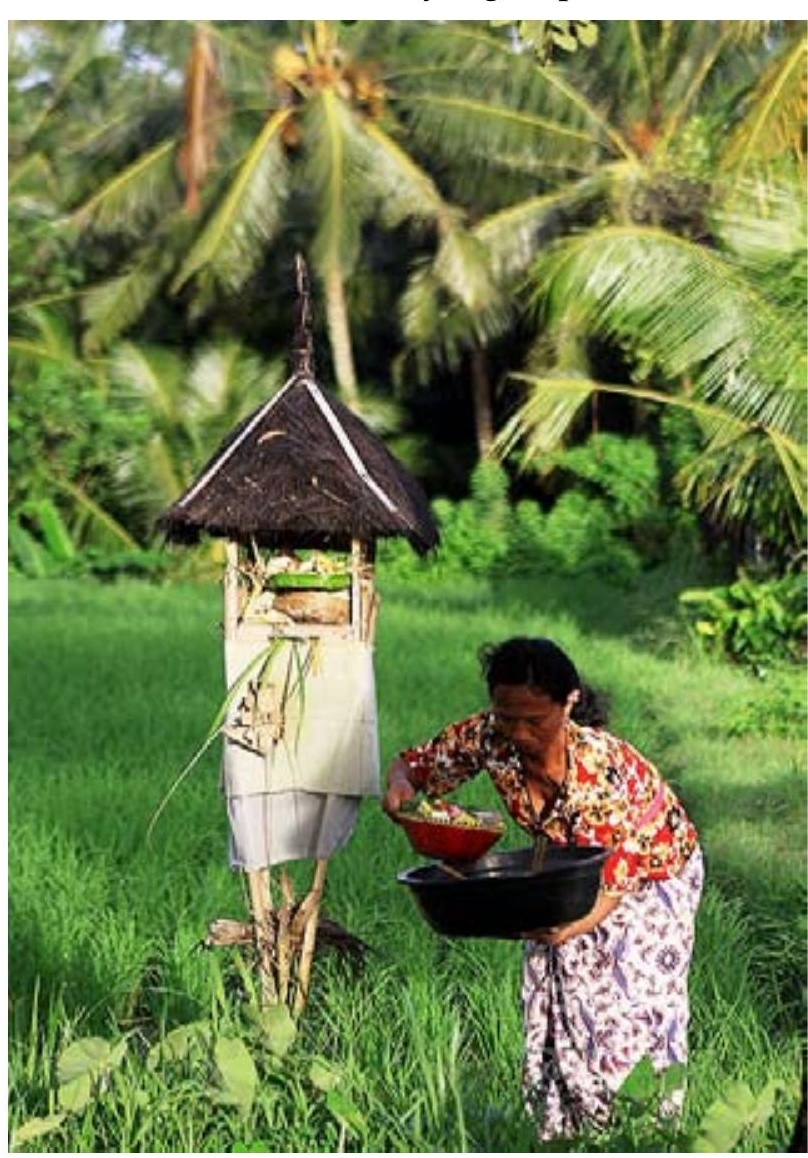




\section{(g) Ritual Meluspusin}

Ritual ini dilakukan ketika tanaman sudah mulai berbuah (berisi) atau padi wau mawoh.

Di tempat lain ritual ini juga disebut mabahin 'padi berbuah'. Upacaranya disertai dengan memasang sanggah catu yang berisi kober gana (bendera) pemujaan kepada Sanghyang Siwa yang ditemani oleh Dewi Uma sebagai istri dewa Siwa. Ada pemujaan kepada dewa-dewa di Pura Ulun Danu (Batur) sebagai pradhana. Berdasarkan hal ini ketika bertani sudah ada pemujaan purusa dan pradana.

Di samping itu ritual juga dilengkapi dengan ketupat sirikan lengkap dengan buah dan pisang, serta lauk ayam panggang. Di hulu sawah (pengalapan) dihaturkan banten sorohan berisi umbiumbian (Bandana, dkk.2010). Selanjutnya dikatakan, ritual ini adalah ritual untuk memohon kepada Tuhan (Ida Sang Hyang Widi Wasa) sebagai Sedan Carik agar padi tidak diserang hama seperti wereng, ulat, burung dan sebagainya.

\section{(h) Ritual Ngadegang Dewa Nini}

Upacara Ngadegang Dewa Nini yaitu upacara untuk membuat simbol Dewi Sri (Nini) dari padi yang terdiri atas simbol Lanang (laki) 108 badih (ikat), istri (perempuan) 54 badih. Sesajen dalam ritual ini adalah sesayut pengambian, dapetan, peras penyeneng sesari jinah bolong 3, tumpeng guru, sesayut ardhanareswari, sodan putih kuning, payasan asoroh, rantasan, naceb sanggah, penjor disertai palawija gantung.

Sesajen tersebut dipersembahkan kepada dewa-dewa yang bersemayam di Pura Besakih. Seluruh sarana sajen tersebut memiliki makna dan simbol yang berkaitan dengan kepercayaan dan tradisi masyarakat Bali sebagai masyarakat yang religius dan taat kepada tradisi adat dan budaya. Dewi Nini sebagai perwujudan Dewi Sri dalam kepercayaan masyarakat Bali adalah dewi yang memberikan kehidupan. Oleh karena itu, petani-petani di Bali selalu melaksanakan ritual ini sebagai ucapan syukur dan terima kasih atas tanaman padi yang telah siap dipanen. 


\section{(i) Ritual Ngampung (manyi)}

Ritual Ngampung (manyi) adalah upacara yang dilakukan saat panen padi tiba yang terdiri atas nasi kuning, dilengkapi dengan kuning telur serta bunga-bunga berwarna kuning. Secara filosofis hal ini menggambarkan kuning adalah warna padi yang telah siap dipanen sehingga digambarkan dengan sesajen yang mayoritas berwarna kuning. Ada yang menarik dalam hal ini yaitu sebelum panen (manyi) harus dilakukan ritual mecaru di bawah sanggah penanduran yaitu rangkaian ritual persembahan kepada makhlukmahkluk seperti Sedahan Be Julit dan Sedahan Yuyu (kepiting), Juru Tumbuk dan Sedahan Padi berupa jaja kukus maunti, pisang sasih nasak, beras merah, putih, kuning ditempatin di takir 5 biji. Tujuannya adalah minta keselamatan dan tidak diganggu dalam acara panen padi. Ritual ini penuh dengan simbol-simbol yang memiliki makna mendalam bagi masyarakat Bali terutama para petani Bali yang masih melaksanakan ritual ini.

\section{(j) Ritual Ngerasakin}

Ritual Ngerasakin (mayah pengrasak) 'membayar pajak' di sawah adalah upacara terakhir setelah panen berakhir. Membayar pajak dalam konteks ritual ini adalah berupa persembahan (pengrasak) kepada Tuhan khususnya manifestasinya yaitu Dewi Sri. Upacara ini adalah sebagai ungkapan rasa terima kasih petani kepada Tuhan atas panen yang telah berhasil dengan sarana ayam, itik, atau babi yang diguling. Makna simbolik ritual ini adalah wujud bakti kepada Tuhan khususnya Dewi Sri dan dewi Uma dan pengikutnya atas segala anugrah-Nya karena telah mendapatkan hasil panen yang baik.

\section{Simpulan}

Dari analisis terhadap ritual pertanian yang dilakukan oleh petani pada lokasi penelitian dapat disimpulkan bahwa ritual pertanian tersebut mengandung makna simbolik yang berkaitan dengan kepercayaan dan falsafah hidup masyarakat Bali. Makna simbolik itu adalah (1) rasa syukur dan ucapan terima kasih kepada Tuhan atas anugrah panen yang baik dan melimpah, (2) permohonan izin kepada Ibu Pertiwi sebagai manisfestasi Tuhan penguasa 
tanah karena para petani akan mengerjakan sawah; (3) memohon keselamatan kepada Tuhan (Dewi Sri, Dewi Uma) agar pertanian dapat berhasil baik, (4) persembahan kepada penguasa sawah agar terhindar dari segala macam hama yang merusak tanaman, (5) menjaga keseimbangan lingkungan. Dalam filosofi masyarakat Hindu Bali hal itu merupakan penerapan konsep Tri Hita Karana.

Banyaknya ritual yang dilakukan oleh petani di Bali menunjukkan makna simbolik sikap religius sehingga setiap tahapan aktivitas pertanian selalu diiringi dengan permohona anugrah dan memohon keselamatan kepada Ida Sang Hyang Widi Wasa. Setiap tahapan riatual memiliki tujuan kebaikan antara lain untuk menciptakan kedekatan hubungan antara petani, agama, dan tradisi budayanya. Seluruh ritual tersebut mengandung makna simbolik tertentu, serta kearifan lokal berupa nilai-nilai budaya yang dianut dan dipedomani sebagai penuntun dalam kehidupan bertani.

\section{DAFTAR PUSTAKA}

Atmaja, Nengah Bawa. 2008. “Kearifan Lokal: Mendekatkan Kesenjangan Antara Teks Ideal dan Teks Sosial Melalui Pikiran Menyintesis dan Multiperspektif". Makalah disampaikan dalam Seminar Nasional Terkait Jubilium Emas (50 th) Fakultas Sastra Universitas Udayana.

Bandana, S. 2005. “Wacana Ritual Penanaman Padi di Selemadeg Barat: Kajian Linguistik Kebudayaan". Tesis Magister Linguistik, Program Studi S2 Linguistik, Program Pascasarjana Univresitas Udayana.

Bandana, S. Dkk. 2010. “Wacana Ritual Pertanian Sebagai Usaha Pelestarian Bahasa dan Budaya Bali : Sebuah Kajian Linguistik Etnologi" . Laporan Penelitian Kementerian Pendidikan Nasional Pusat Bahasa . Denpasar : Balai Bahasa Denpasar.

Bonvillain, Nancy. 2003. Language, Culture, and Communication. The Meaning of Messages. New Jersey : Printice Hall

Endraswara, Suwardi. 2012. Metodologi Penelitian Kebudayaan. Yogyakarta : Gadjah Mada University Press

Gara, I.W. 2006. “Wacana Samodana Usaba Sambah pada 
Masyarakat Tenganan Pegringsingan: Sebuah Kajian Linguistk Kebudayaan." Disertasi Pada Program Studi S3 Linguistik Program Pascasarjana Universitas Udayana

Griya, W. 2000. Transformasi Kebudayaan Bali Memasuki Abad XXI. Denpasar : Bali Post

Hymes, D.H. 1964. Language in Culture and Society. A Reader in Linguistics and Anthropology. New York: Harper International Edition

Iskandar, Johan. 2012. Ekologi Perladangan Orang Baduy. Pengellaan Hutan Berbasis Adat Secara Berkelanjutan. Bandung: PT Alumni

Kersten, J, SVD. 1980. Bahasa Bali. Kamus Bahasa Lumrah. Ende: Nusa Indah

Koentjaraningrat. 2002. Kebudayaan Mentalitas dan Pembangunan. Jakarta: PT Gramedia Pustaka Utama

Netra, I.M. 2012. “Wacana Ritual Melong Pare Bulu Komunitas Petani Adat Bayan, Lpmbok Barat : Kajian Etnopragmatik. Disertasi. Program Studi S3 Linguistik Program Pascasarjana Universitas Udayana.

Pastika, I Wayan. 2002. "Nuansa Gender dalam Bahasa Kita". Dalam Srikandi : Jural Studi Jender. Vol.2, No.2, Tahun 2002. Denpasar : Pusat Studi Wanita Lembaga Penelitian Universitas Udayana.

Sirtha, N. 2008. Subak, Konsep Pertanian Religius : Perspektif Hukum, Budaya, dan Agama Hindu. Surabaya: Paramita

Radclife-Brown, A.R. 1979. Structure and Fuction in Primitive Society: Essays and Adresses. London and Henley : Routledge \& Kegan Paul

Spradley. J.P. 1997. Metode Etnograf. EdisiTerjemahan oleh Misbah Zulfa Elizabeth. Yogyakarta ; PT Tiara Wacana Yogya

Suaka, I Nyoman. 2013. “ Folklor Bhatari Sri Kearifan Lokal petani di Balik Warisan Budaya Dunia" dalam Folklor dan Folklife Dalam Kehidupan Modern. Endraswara dkk. (ed.). Yogyakarta: Ombak.

Subak Kedua. 1993. Aci-aci Subak Kedua. Pesedahan Yeh Lauh. Denpasar, Kecamatan Denpasar Barat, Desa Peguyangan Kangin 
Sudikan, Setya Yuwana. 2013. “ Pengetahuan dan Kearifan Lokal dalam Tradisi Lisan Nusantara: Pengetahuan Nilai-nilai Kebhinekaan untuk Indonesia Masa Kini dan Masa Depan" Makalah Seminar Nasional Tradisi Lisan dalam Pendidikan, FPBS IKIP Saraswati Tabanan 26-27 April 2013.

Turner, Victor. 1967. The Forest of Symbols: Aspect of Ndembu Ritual. London : Cornell Paperback, Cornell University Press 